Прегледни чланак

Katarina S. Živanović, Ph.D. Student

University of Novi Sad

Faculty of Law Novi Sad

kaca_zivanovic@yahoo.com

\title{
LIMITATION OF THE FREEDOM OF MOVEMENT OF A SUSPECT IN A PRELIMINARY CRIMINAL PROCEDURE
}

\begin{abstract}
The foundations of the contemporary, democratic society which are based on the principle of justice protection of the fundamental societal values and the rule of law, designate free and unhindered implementation of the proclaimed human rights and freedoms as the postulation of its order.

Howewer, in certain cases, in order to acomplish the criminal law protection of the societal values, it is necessary to digress from the rights and freedoms that are guaranteed both on the national and internatonal level, whenever this is justified of course. Within the constitutions of modern countries, such limitations are mostly being brought down only to certain "exceptional" cases in strongly standardized conditions. Therby we face an exception from the proclaimed right to personal freedom, where such limitation is allowed to certain extent and purpose without interfering in the essence of the guaranteed rights, during the proceedings and in cases that are determined by the law.

Limitation of the freedom of movement of a suspect is being designated by a resolution in written form established by the responsible judicial authority, primarily in order to conduct criminal proceedings. Nevertheless, in order to achieve the efficiency of a criminal proceedings and to support the decisive fight against the criminality, the right to limit the freedom of movement in a form of arrest and keeping in custody has been granted to the other State Authorities as well.
\end{abstract}

Keywords: limitation of the freedom of movement, a suspect, the police, an arrest, a detension. 


\section{LIMITATION OF THE FREEDOM OF MOVEMENT \\ OF A SUSPECT IN THE PRELIMINARY CRIMINAL PROCEDURE IN THE REPUBLIC OF SERBIA - HISTORICAL ASPECT}

\section{The power of the authorities and the manner of restricting the freedom} of movement of the suspect. The limitation of the freedom of movement of a suspect in a proceedings that comes before the formal criminal proceedings is not a new criminal procedural institute. However, its significance and the conditions for its implementation changed over time, with the tendency of increasing protection and proclaiming the rights and freedoms of the persons towards which these measures are being taken, as well as the roles that the authorities have in relation to the restriction of the freedom of movement of the suspect.

From the very beginning of the legal foundation of criminal proceedings, the legal authorities of the procedural bodies have been standardized, depending on the stage of the procedure in which they are applied. The legal beginning of the concept of the course of criminal proceedings was set up by the Code of Criminal Procedure in 1865, foreseeing the following: a preliminary investigation and proceedings before a court - a search ${ }^{1}$. By standardizing the general preliminary investigation (as the first part of the previous investigation, while as the second part of the preliminary investigation it foresaw prosecution, i.e. judicial investigation), the Code gave an important role to the internal affairs bodies. This role meant starting an investigation once the criminal offense was determined. ${ }^{2}$ Within the scope of its authority, the police authorities could deprive the suspect of his freedom, or determine a temporary (police) detention with the main goal of bringing the suspect to the competent investigator. ${ }^{3}$

The further criminal trial evolution of this institute was based on the principles laid down by the 1865 Code, bearing in mind that the institution of deprivation of liberty of the suspect was primarily carried out through detention. However, what was different was who of the competent authorities and under what conditions could order the stated measure. Thus, the Code of Criminal Procedure of $1929^{4}$

${ }^{1}$ Miroslav Popović, „Fundamentals of normative regulation of criminal proceedings in the Principality of Serbia (1846-1865)", Proceedings of the Law Faculty in Niš, 71/2015, 91.

${ }^{2}$ Ibid.

${ }^{3}$ Tanja Kesić, Position of the Suspect in Pre-trial Proceedings, Master Thesis, Belgrade 2005, 120: stated as in: Dragana Čvorović, Deprivation and Limitation of Freedom by the Police, Doctoral Dissertation, Belgrade 2015, 283.

${ }^{4}$ The Code of Criminal Procedure, Official Gazette no. 45-XX/1929. 
foresaw the obligatory deprivation of liberty ${ }^{5}$ of the suspect as well as optional detention. ${ }^{6}$

Both types of detention could have been determined only by the judicial authority, in a written order (Article 115). However, from this procedural rule, Art. 116, the Code standardized an exception to the treatment of the police, since it (along with the undesignated judge) could have ordered the measure of detention (compulsory and optional) for the purpose of bringing the suspect to the investigating judge. Determination of the detention by the non-judicial body was conditioned by the danger of delay, or it was permitted if it was not possible to request an order from the competent judge earlier.

Unlike the 1929 statutory provision, which provided for the possibility of deprivation of the suspect's liberty by the interior affairs authority as an exception, the Criminal Procedure Act of $1948^{7}$ provided such a power of the police authority as a rule, since it (Article 141 ) stated that "a detention order could have been ordered by an investigative authority or a public prosecutor in a written order", that is, this authority was no longer exclusively within the jurisdiction of the judicial authorities. Regarding the conditions for detention, the Law retained the same material condition - the basis of the suspicion that a certain person committed a criminal offense, which required the fulfillment of one of the law predicted conditions. ${ }^{8}$

In addition to this particular manner of deprivation of liberty of the suspect, where the Law stipulates that "detention may be ordered" (Article 140, paragraph 1), the institution of compulsory detention was also standardized if "a special law for a particular criminal offense requires detention" (Article 140, paragraph 2). Another difference in relation to the 1929 Code of Conduct is that, on the basis of the order of detention (of the internal affairs authorities), a person could be detained

${ }^{5}$ The compulsory deprivation of liberty could be determined by a judicial authority, in the case of the assumptions fulfilled by the Code and regulated by the Article 113, paragraph 1 of the Code, requiring their cumulative fulfillment. The first condition concerned the degree of conviction that a criminal offense was committed, while the second condition concerned the prescribed punishment for the committed criminal offense.

${ }^{6}$ Article 113, para. 2, t. 1-4 of the Code provided the following conditions for determining optional detention: "In the case of any other criminal offense, the investigating judge may order the suspect to be detained: 1 . when he/she is found committing the offense; 2 . if he/she is hiding or being prepared for escape, if he/she is a vagrant or an unidentified person, if he/she has no personal documents, or if there are other important reasons for which he/she might think of escaping; 3. if there is a reasonable fear that he/she will set back the investigation, either by attempting to influence the witnesses, expert witnesses or accomplices, or by seeking to destroy the evidence of the offense; 4. when special circumstances justify fear, that the suspect will repeat the crime or that he/ she will try to finish the an offence left undone, or commit an offence that poses danger to others.

${ }^{7}$ Criminal Procedure Code, Official Gazette of the FPRY, number 97, year IV of November 6, 1948.

${ }^{8}$ Which were the conditions for determining optional detention in the earlier legal solution. 
for a maximum of three days. However, the extension of the duration of the detention period could not be determined by the investigating authority which first ordered the detention. This could be done only on the basis of the decision of the public prosecutor, for three months, counting from the date on which the suspect was placed in custody (Article 142, paragraph 1 of the Law).

Furthermore, when it comes to the authorities that may impose detention as a measure of the deprivation of liberty of the suspect, the Code of Criminal Procedure of $1953^{9}$, prescribed such a measure within the original jurisdiction of the internal affairs authorities, bearing in mind that they could decide to order detention (Article 183). The procedural solution to the restriction of the freedom of movement of the suspect was almost entirely taken from the previous legal solution, both in terms of the conditions and the terms of the action, with minor changes. ${ }^{10}$

However, one of the most important novelties was that the extension of detention was no longer decided by the public prosecutor, but by the competent judicial authority - the investigating judge or the judge of the district court.

The 1977 Code of Criminal Procedure ${ }^{11}$ proscribed the competence of the internal affairs authorities in Article 1512, according to which they could have

${ }^{9}$ Code of Criminal Procedure, Official Gazette of the FPRY, number 40, year 9 from September 30, 1953.

${ }^{10}$ Article 182, paragraph. 1, the Code foresees the following: "The custody will always be determined against a person for whom there are grounds for suspicion that he/she has committed a criminal offense for which the law provides for a death sentence", and paragraph 2 of the same article stipulates that "If there are grounds for suspicion that a certain person has committed any other criminal offense, custody may be determined ", however it was necessary to fulfill certain legal requirements. The investigating judge, to whom the detained person was brought to, after the hearing, could make two decisions: 1 . to release the person who was detained; or 2 . to submit a proposition to the public prosecutor for the opening of an investigation (within three days, and if he does not bring the said proposition within that time frame, the person deprived of liberty would be released as provided for in Article 184,paragraphs 1, 2 and 3 of the Code).

If a person was detained by the decision of the internal affairs authority, the said authority had the duty to interrogate the detained person within 24 hours of detention. Thereafter, an internal affairs authority (or a district court judge, if he had issued a detention order), should have issued one of the following decisions according to which: 1. the detained person could be released, 2 . detained or 3. conducted to the competent judicial authority (investigating judge), in accordance with Article 185. According to the decision of the internal affairs authority, the suspect could have been kept in detention for a maximum of three days, from the moment he was placed in custody. Outside of that time frame, the suspect could have remained detained provided that the decision to extend the custody was made (Article 186).

${ }^{11}$ Criminal Procedure Code, Official Gazette of the SPRY, number 4, year XXXIII of 14, January 1977.

${ }^{12}$ Article 151, paragraph 1 of the said Law reads: "If there are grounds for suspicion that an offense that needs to be prosecuted in the line of duty was made, the authorities of the internal affairs are obliged to take the necessary measures to find the perpetrator of the criminal offense, that the perpetrator or the accomplice does not hide or escape, to discover and secure traces of criminal offense and objects that can serve as evidence, as well as to collect any information that might be useful for the successful conduct of criminal proceedings." 
deprived the person ${ }^{13}$ of the freedom, if the conditions for determining detention ${ }^{14}$ were met, with the existence of reasonable doubt. However, the Law also foresaw, although exceptionally, the possibility of the officials of the internal affairs authorities to detain a suspect before the initiation of the investigation ${ }^{15}$, as well as when the investigating judge entrusted them with the commission of certain investigative actions under Article 162, para. 4 of this Law, if there were reasons for determining detention.

By the Criminal Procedure Code of the Federal Republic of Yugoslavia ${ }^{16}$, certain restrictions were imposed on the police authorities in terms of arresting a suspect, since the police could no longer order detention, although it kept the same conditions for deprivation of liberty of a suspect - a reasonable doubt and one of the reasons for detention. ${ }^{17}$

Namely, in the event of fulfilling the above conditions, the police could have deprived a person of their liberty, but the duty to bring such a person to the competent judicial authority (i.e. the investigating judge) was prescribed within the time limit determined by this Code. ${ }^{18}$

There was an exception from the abovementioned practice, in case the conditions for detaining a person were met. The person thus deprived of his liberty

${ }^{13}$ Article 195, paragraph 1 reads as follows: "Authorized officials of the internal affairs authorities may deprive of their liberty any person if there is any reason provided for in Article 191 of this Law, but are obliged to bring such a person without delay to the competent investigating judge ...", paragraph 2 of the said Article "If it was not possible, due to unavoidable impediments, that a person deprived of liberty is brought to the investigating judge within 24 hours, the official person is obliged to explain this delay in particular. The explanation of the delay is necessary even when the implementation was carried out at the request of an investigative judge ", and finally, paragraph 3" If the investigating judge is not in a position to make a decision on detention within the deadline, due to a delay in bringing the suspect to the judge, he/she is obliged to decide on detention immediately after a person deprived of his/her liberty was brought to him/her".

${ }^{14}$ This law also made a distinction between compulsory detention (prescribing conditions for its determination: reasonable doubt and the death penalty) and detention which could have been determined, where he retained the same condition of suspicion - a reasonable doubt was established, and in case it was not provided for the death penalty, but there was one of the statutory requirements of Art. 191, para. 2, t. 1, 2, 3 and 4. According to this Law, custody was primarily determined by the decision of the competent investigating judge.

${ }^{15}$ Article 196 of the Law made an exception, since it prescribed the authorisation of the internal affairs authorities to impose a detention that could last for three days, and in the circumstances provided by this Law.

${ }^{16}$ Code of Criminal Procedure of the FR of Yugoslavia, Official Gazette FRY, no. 70/2001 and 68/2002 and Official Gazette or the RS, no. 58/2004, 85/2005, 115/2005, 85/2005 - dr. Law, 49/2007, 20/2009 - dr. law and 72/2009).

${ }^{17}$ Which, as stated in the previous legal solution, could have exceptionally lasted for three days.

18 The Code, in the Article 227, paragraph 3, prescribed a deadline in which the police authority was obliged to bring the person deprived of liberty to the competent judge -8 hours. However, if " due to unavoidable impediments, the conduct of a person deprived of liberty lasted more than 8 hours", the police authority was obliged to specifically explain such a delay. 
(in accordance with Article 227, paragraph 1, as well as the primarily ${ }^{19}$ and subsequently ${ }^{20}$ suspected person, the police authority could detain, but only exceptionally and in order to collect information or hearings, "no longer than 48 hours from the moment of deprivation of liberty, or responding to a summon ", as foreseen by Article 229, paragraph 1 of the Code. The Code prescribed the duty of the internal affairs authority to immediately order the detention and immediately inform the investigating judge, as well as to summarize all rights that were prescribed with this $\operatorname{Code}^{21}$ to the suspect.

2. Treatment of a person deprived of liberty. When it comes to the treatment of authorities who, by applying their authorizations proclaimed by the law, deprived a suspect of his/her liberty, the rules proclaimed by the initial legal solutions existed during the evolution of this process institute in Serbia. Namely, the hearing of the detained person was prescribed as an obligation of the authority that ordered the measure of deprivation of liberty 22 (Article 116, paragraph 2 of the 1929 Code). After the hearing, (by the police), the person would be released or conducted to the competent investigating judge. ${ }^{23}$ Despite the fact that a person deprived of liberty was questioned by the police authorities, the investigating judge had the duty to hear each person in custody within 24 hours. ${ }^{24}$

After hearing the suspect, the judge had to immediately issue one of the decisions on the basis of which the person could be released or placed in an investigative prison (in accordance with Article 118, paragraph 2). The person who was deprived of liberty in such way had to be informed immediately, at the very moment of detention, by the competent authority, about the order in detention. ${ }^{25}$ In a similar, almost identical way, the actions of the competent authorities were prescribed by the 1948 Act, the 1953 Code, and the 1977 Act.

${ }^{19}$ The person summoned to provide information as a suspect, who will be informed about the right to a lawyer in the summons (Article 226, paragraph 7).

${ }^{20}$ The summoned citizen, for whom the police authorities, when taking the testimony, estimated they could be a suspect in a particular case. In that case, the acting authority had the duty to immediately inform the suspect about the act for which he was being charged and the grounds of suspicion, the right to take a defender who will attend his further hearings, that he/she is not obliged to answer questions without the presence of his/her defender" as foreseen by Article 226, paragraph 8 of the Code.

${ }^{21}$ See the provisions of Article 229 of the said Code.

22 The foregoing was determined in such a way that the person deprived of liberty had to be questioned immediately, and at the latest within 24 hours.

${ }^{23}$ If the existence of a legal basis for further detention could not be established, the detained person would be released. Otherwise the legislator specified the deadline of 48 hours after the hearing, in which the police had to conduct the suspect to the competent investigating judge in accordance with Article 116, paragraph 2 Code.

${ }^{24}$ However, this Code allowed the time for undertaking the said action to be exceptionally extended to three days, in accordance with Article 118, paragraph 1.

${ }^{25}$ Exceptionally, if this is not possible, the said could be communicated no later than within 24 hours from the time of the detention (Article 115, paragraph 1). 
3. Civil Liberties Institute. In addition to the detention of the suspect by the state authority, all criminal procedural solutions provided for the possibility of such a restriction of the freedom of movement by each person in the event of a flagrant delict.

It was the very 1865 Code that prescribed the ability of each individual (citizen) to commit the deprivation of liberty of a person found committing a criminal offense, with the obligation to bring such a person to the competent investigator or police authority. ${ }^{26}$ The following criminal procedural decisions kept the institution of a civil deprivation of liberty in the event of finding a person committing an offence, while modifying the condition relating to the act for which the person could have been deprived of his liberty in that way. ${ }^{27}$

4. The rights and the position of a person deprived of their liberty. Regarding the legal position of the suspect in the previous phases of the criminal proceedings, it is evident that the provisions of the initial criminal procedural decisions were far from the ideal of justice and the principles of modern criminal proceedings, bearing in mind the former legal proclamation of the obligatory absence of the defense counsel when the defendant was examined during the inquest and investigation phase. ${ }^{28}$

The provisions of the Code of Criminal Procedure of 1929 improve the procedural position of the suspect, having in mind certain provisions of this Code 29 - at the first examination, as well as in the announcement of the order for detention, the suspect (Article 59) should have been educated by the investigative judge on the right to a defender (which he can take). ${ }^{30}$

${ }^{26}$ D. Čvorović, 282.

27 Thus, the 1929 Code retained the same conditions, with Article 114, par. 1, t. 1-3 prescribing cases of finding an individual committing an offence, first and foremost, in order to ensure a certain degree of legal certainty for those who could have performed such an arrest. The 1948 Law prescribed that it was necessary to have a criminal offense for which the law provided for a sentence of institutional deprivation of liberty, or a prison sentence; while the legal solution from 1953 (Article 182, paragraph 3) provided that it was necessary that it be a criminal offense for which prosecution was undertaken ex officio. Such a legislator's solution was also found in the 1977, 2001, and 2011 legal provisions. Also, each of the aforementioned legal provisions envisaged the possibility that persons who deprived of liberty a suspect found committing an offence simply inform the competent public authority (judicial or police) if they could not immediately bring such a person to the competent authorities.

${ }^{28}$ D. Čvorović, 282.

${ }^{29}$ Article 3 of the Code prescribed the duty of all bodies involved in the conduct of criminal proceedings to equally appreciate the circumstances that accuse the defendant and the circumstances that serve him, as well as to teach him about his rights; Article 57 proscribes that the defendant may have a defender at any time in the proceedings for a criminal offense, and Article 60 proscribed the compulsory defense cases.

${ }^{30}$ The person in custody could communicate with the defense attorney in an oral or written manner (Article 67). Also, the Code prescribed the principle of respecting a person and the principle of honor (as far as possible, Article 123), as well as the duty of all procedural authorities in 
The Criminal Procedure Code of 1953 brought significant progress with regard to the position of the suspect deprived of liberty by the competent authorities during the fulfillment of the procedural assumptions, since in addition to the right to defense (which was possible during the entire procedure) it brought a significant shift that is reflected in the principle of the presumption of innocence (Article 3 of the Code) as well as in the right to compensate for property damage if the defendant is unlawfully deprived of his liberty by detention or by being kept in the investigative imprisonment.

In addition to the already proclaimed obligation of the authorities to take custody of the witness for as short a time as possible, the 1977 Code prescribed the principle of urgency in dealing of the competent authorities while the person is in detention, while the Code of 2001 proclaimed the institute of compulsory defense in case of retention. ${ }^{31}$

\section{LIMITATION OF THE FREEDOM OF MOVEMENT OF A SUSPECT IN A PRELIMINARY CRIMINAL PROCEDURE- CERTAIN COMPARATIVE-LEGAL SOLUTIONS}

In what way the limitation of the freedom of the suspect is regulated in the two world's legal systems, Anglo-Saxon and European-continental, we will see in the representation of the basic solutions to the positive regulation of the United States and certain European countries - Germany, Switzerland, Italy and France.

Bearing in mind the procedural provisions in accordance with which the measure of deprivation of liberty of the suspect in the legal system of common law can be taken, the existence of reasonable doubt is considered a material condition, and as Simović states, the arrest which is not based on the stated degree of doubt represents an unfounded arrest and violation of the fourth amendment which regulates the area of protection of the rights to the security of the person in the US Constitution. ${ }^{32}$

Due to the fulfillment of the aforementioned material conditions, arrest in the law of the United States may be executed with or without an arrest warrant, ${ }^{33}$

the criminal procedure to take into account the duration of detention and investigative imprisonment, meaning that these should last as short as possible (Art. 129, paragraph 1).

${ }^{31}$ Immediately after the retention decision was made, the suspected person had to have a defense counsel whom could be chosen by him/herself, or the defense attorney would be appointed ex officio by the body of conduct (Article 229, paragraph 6 of the Code).

${ }^{32}$ Miodrag Simović, ,Arrest and search warrant in the law of the United States of America”, Yearbook of the Faculty of Law, University of Banja Luka, 33/2011, 74.

${ }^{33}$ It is important to list the cases in which the police cannot apply this authorization without an arrest warrant. These are the following cases: the police cannot arrest a person in his/her home without an arrest warrant, unless there are special circumstances or consent; also, a person 
and the treatment of the arrested person depends on whether the person will be immediately brought to the investigating authorities or held at the police station. ${ }^{34}$

Therefore, the suspect may be arrested by the police, under the above conditions. Exceptionally, the suspect may be arrested without a warrant if the offense is committed in the presence of the police. ${ }^{35}$

A person deprived of liberty without delay, and at the latest within 48 hours, must be administered by the judicial authority, and the hearing of the suspect by the police is justified in order to decide whether the suspect will be released or will be carried out by the competent authority to the court. ${ }^{36}$

In the countries of the European-continental legal tradition, the importance of the pre-trial proceedings derives from the evident influence on the outcome of the main criminal procedure. ${ }^{37}$ Therefore, when it comes to the way in which the internal affairs authorities act during the pre-trial procedure, it is largely unified.

The German criminal proceedings $\mathrm{Law}^{38}$ provides for the institution of a civil deprivation of liberty ${ }^{39}$ as well as the deprivation of liberty by the internal affairs authorities, which, apart from the flagrant delict or the person sought, may exercise this power in the event of a cumulative fulfillment of the conditions for taking this measure of procedural coercion (reasonable doubt and one of the reasons for detention), with the risk of delay. A person deprived of his liberty shall immediately be acquainted with the law provided rights (Articles 114a to 114c), and it is necessary to take the matter to the competent court (immediately and at the latest one day after the deprivation of liberty). The judge is obliged to bring the suspect to the hearing immediately, and at the latest on the next day. In the

cannot be arrested in the home of a third party without a search warrant and an arrest warrant. However, there is an exception to the aforementioned legal rule, that is, the police can perform an arrest without order in the above ways, if the reasons of urgency require so or if there is the consent of the person. Joshua Dressler, Understanding Criminal Procedure, New York, 1997, 148: Stated as in: M. Simovic, 75.

${ }^{34}$ D. Čvorović, 455.

${ }^{35}$ M. Simovic, 74.

${ }^{36}$ Ronald, J. Bacigal, Criminal law and Procedure, Delmar, Cengage learning, 152. Stated as in.:D. Čvorović, 473.

${ }^{37}$ Aleksandar Bošković, Zoran Pavlović, ,Problematic review of the organization of the previous criminal proceedings in the Republic of Serbia and Croatia", Croatian Journal of Criminal Sciences and Practice, No. 1/2016, Zagreb, 189.

38 The German Code of Criminal Procedure, Federal Law Gazette Bundesgesetzblatt, Part I p. 1074, 1319, 410/14, https://www.gesetze-im-internet.de/englisch_stpo/englisch_stpo.html, 11.03.2018.

39 "Any person found committing a criminal offense or a person being sought and is suspected of escaping or whose identity cannot be immediately determined can be retained by anyone without a court order," See the Code of Criminal Procedure of the Federal Republic of Germany, UNIVERSITY PRESS - Magistracy of editions Sarajevo 2011, 71, The German Code of Criminal Procedure, Federal Law Gazette Bundesgesetzblatt, Part I p. 1074, 1319, 410, https://www.gesetze-im-internet.de/englisch_stpo/englisch_stpo.html, 11.03.2018. 
event that the judge finds that the reasons for deprivation of liberty no longer exist, or that it is no longer justified, he/she will order the release of the suspect. Otherwise, by the order of the competent prosecutor (or ex officio if the prosecutor is not available), a judge may issue either a decision on detention or a decision on accommodation in an institution..$^{40}$

The Criminal Procedure Code of Switzerland ${ }^{41}$ almost identically determines the authorities of the police officials in the case of deprivation of liberty of the suspect, primarily having in mind the procedural provisions for the deprivation of liberty of a person found committing a criminal offense or for which there is an arrest warrant or is being sought (Article 217).

The person arrested in this way can be detained by the police for a maximum of 3 hours. Such authority belongs to every citizen in terms of civil arrest, after which the arrested person must be handed over to the police authority as soon as possible. After the arrest, the police will inform the suspect about his rights and the reasons for the arrest. The competent public prosecutor is being immediately informed about the arrest. The police are authorized to hear the suspect and take legal measures and actions in order to substantiate or reject the allegations and grounds for detention. ${ }^{42}$

Almost identical procedural rules governing the pre-trial phase are also found in the Criminal Procedure Code of the Republic of Italy ${ }^{43}$, which also makes a distinction between compulsory ${ }^{44}$ deprivation of liberty and deprivation of liberty prescribed by the law of the competent state authority ${ }^{45}$ as well as the possibility of arrest by the citizens. ${ }^{46}$

${ }^{40}$ More about that in Criminal Procedure Code of the Federal Republic of Germany, UNIVERSITY PRESS - Magistracy of editions Sarajevo 2011, 72, The German Code of Criminal Procedure, Federal Law Gazette Bundesgesetzblatt, Part I p. 1074, 1319, 410, https://www.gesetze-im-internet.de/englisch_stpo/englisch_stpo.html, 11.03.2018.

${ }^{41}$ Criminal Procedure Code of Swiss Confederation, (2007, amended 2017), https://www. legislationline.org/documents/section/criminal-codes/country/48/Switzerland/show, 01.03.2018.

${ }^{42}$ If it is found that there is no basis for determining detention, a person will be released, otherwise the person will be prosecuted. The time limit within which a police authority must make a decision to release a person or to bring it to the competent public prosecutor is 24 hours.

${ }^{43}$ Codice di Procedura Penale, https://www.legislationline.org/documents/section/criminal-codes/country/22/Italy/show, 07.03.2018.

${ }^{44}$ In the case of a flagrant delict, prescribing criminal offenses or the range of penalties that can be imposed for a committed criminal offense.

${ }^{45}$ It is the right of an authorized person to deprive of liberty a person found committing a criminal offense (which has not been done by negligence) in case of certain criminal acts prescribed by law (this distinction is made in relation to the level of social danger, injury and endangerment of protected goods of the man, society and state) or prescribed by the seriousness of the penalty.

${ }^{46}$ In this way, the arrested person needs to be administered to the police as soon as possible. In order for a person to be deprived of his liberty by a citizen, it is necessary that such a person is found committing a criminal offense for which he/she may be prosecuted ex officio. 
In addition to the case of the offender being caught committing an offense, authorized police officers can keep the suspect detained on their $\mathrm{own}^{47}$, before undertaking the actions prescribed by the public prosecutor. ${ }^{48}$

In French law $^{49}$, a criminal procedural institution restricting the freedom of movement of a suspected person is standardized so that the judicial police ( $j u$ dicial police officer) is given the authority to arrest and detain a person in the event that there is one or more credible grounds for upholding suspicion of committing or attempting to commit a criminal offense. The police are obliged to inform the competent public prosecutor about the arrest. A person arrested and detained ${ }^{50}$ cannot be held in custody for more than 24 hours. ${ }^{51}$ Upon expiration of 24 hours of police detention, a person will either be released or will be sent to the competent public prosecutor, according to his instructions..$^{52}$ From the procedural rule that the suspect in police custody may be kept for 24 hours, exceptions are provided, for certain offenses where police custody may last 48 hours or 72 hours (see Articles 63-4).

${ }^{47}$ If there is an inability to determine the identity of the suspected person or if the circumstances indicate a danger of escape.

${ }^{48}$ Also, the police will determine the detention even if the identity of the suspect is subsequently determined or there is a danger that the suspect will try to escape, so it is impossible to wait for the decision of the prosecution authority due to the necessity of an urgent action. The police will immediately inform the public prosecutor about this and the person deprived of liberty will be informed about the right to a defense counsel, or he/she will be appointed one ex officio in case of compulsory defense. However, if it is determined that there are no reasons for detaining the suspect (Article 189, paragraphs 1 and 2), that is, to meet the requirements of paragraph 2 of Article 389, the police must bring the person to the public prosecutor or the public prosecutor will come to make the final decision. The deadline for enforcement is 24 hours, but not beyond this, which means that after that time the suspect is released without the final decision of the public prosecutor, unless the public prosecutor has approved the delay. It is also stipulated that the detention and arrest of a suspect become ineffective if the time limit referred to in paragraph 3 of Article 386 is not met, that is, if the 24 -hour period is exceeded. The Code further foresees that the public prosecutor may approach the hearing of the suspect. See Italian Criminal Procedure, Faculty of Law, University of Rijeka, Rijeka 2002, Codice di Procedura Penale, https://www.legislationline.org/documents/section/criminal-codes/country/22/Italy/show, 07.03.2018.

${ }^{49}$ Code de procédure pénale, https://www.legislationline.org/documents/section/criminalcodes/country/30/France/show, 04.03.2018.

${ }^{50} \mathrm{~A}$ police officer is also obliged to instruct the person deprived of liberty of the rights proposed by this Law, as well as about which criminal offense he/she is being charged with.

${ }^{51}$ However, there is a possibility to extend the duration of detention for 24 hours if there is a written authorization of the competent public prosecutor.

52 The subsequent period of police custody may be approved by the competent public prosecutor only after the suspect is brought before the prosecutor. Exceptionally, an extension of the duration of police detention may be granted only on the basis of written permission from the public prosecutor. 


\section{POLICE ARREST IN POSITIVE DOMESTIC LAW (ARTICLE 291 OF THE CRIMINAL PROCEDURE LAW)}

As one of the measures of procedural coercion in the preliminary procedure (as the first procedural stage preceding the formal investigation by the public prosecutor, and in its content, it represents a kind of procedural "substitute" to the former pre-trial procedure ${ }^{53}$ ), which the internal affairs authority - the police is undertaking in the case of the conditions fulfilled in accordance with the Code of Criminal procedure ${ }^{54}$, the deprivation of liberty of the suspected, or police arrest, is standardized.

Namely, the restriction of personal liberty, by deprivation of liberty of the suspect, is possible, first of all, on the basis of a court decision. However, from the legal position of the police, as the first link in the chain of social responses to unlawful behaviors, it is logical to authorize this administrative authority to short-term detention of the suspect in prison before taking him/her to the judicial authority. ${ }^{55}$

The Code of Criminal Procedure of the Republic of Serbia proclaims that the arrest may be: police arrest (Article 291 of the Code) and arrest in the commission of a criminal offense, the so-called civil arrest (Article 292 of the Code). Instead of the earlier term deprivation of liberty, the legislator decided to use the term arrest, which, according to some authors ${ }^{56}$, is justified.

A positive procedural solution provides that the notion of deprivation of liberty is a generic term, and that the deprivation of liberty, in accordance with Art. 2, para. 1, p. 23 - "arrest, detention, ban on leaving the apartment, custody and staying in an institution which, in accordance with this Code, shall be counted as custody".

In spite of the establishment of the lowest level of confidence (reasonable doubt $^{57}$ ) that is necessary for the conduct of pre-investigative and investigative proceedings, the legislator nevertheless, when standardizing the basis of the deprivation of liberty of the suspect by the police, prescribes reasonable doubt in an attempt to raise the level of protection of human rights and fundamental freedoms,

\footnotetext{
${ }^{53}$ Milan Škulić, Tatjana Bugarski, Criminal Proceedings, Faculty of Law in Novi Sad, Novi Sad 2015, 357.

${ }^{54}$ Code of Criminal Procedure, Official Gazette of the RS, no. 72/2011, 101/2011, 121/2012, 32/2013, 45/2013. and 55/2014.

${ }^{55}$ Saša Knežević, "Limitation of personal liberty by detaining the suspect", Proceedings of the Law Faculty in Novi Sad, 1/2011, 168.

${ }^{56}$ Bearing in mind that this is a term that is domesticated and fully recognizable, so that it makes it possible to clearly distinguish one of the existing forms of deprivation of liberty. Goran P. Ilić et al., Commentary on the Code of Criminal Procedure, Official Gazette, 2016, 739.

57 "The reasonable doubt involves a certain degree of possibility that someone has committed a crime, and this possibility is still less than the opposite possibility that he did not do it." See Snežana Brkić, "Critical review of the regulation of the investigation into the CPC of Serbia from 2011”, Proceedings of the Law Faculty in Novi Sad, 2/2015, 565.
} 
as well as the procedural guarantees of arbitrary treatment by the public authorities. In addition to reasonable doubt, the Code precisely states the need for the existence of one of the conditions for determining detention. ${ }^{58}$

When executing this process of procedural coercion, the police do not pass any special decision, so there is no possibility of investing a special legal remedy against the said action, and control of the legality of treatment in these cases is realized in the further stages of the procedure. ${ }^{59}$ Such a legal solution is justified, and the reasons for its justification are found primarily in practice, since otherwise it would be difficult or even deliberate the attempt of the legislator to achieve the principles of effective fight against crime.

The basic task of the police is to bring the arrested person to the prosecutor without delay. Any detention of a person not caused by objective difficulties of prompt delivery to the prosecutor would constitute an illicit conduct by the police. In this regard, the police is obliged to submit a report to the public prosecutor in which the reasons and the time of the arrest will be clearly stated. ${ }^{60}$

Every enforcement of a suspect that lasted more than eight hours (Article 291, paragraph 3) must be specifically explained, on which the public prosecutor shall make an official note. Following the implementation of the arrested person by the public prosecutor, pursuant to Article 293 of the Code, the public prosecutor is obliged to inform the arrested person about the rights (from Article 69, paragraph 1 of this Law) and to question him/her. Also, the arrested person will be allowed to inform his/her defender about the above. ${ }^{61}$

${ }^{58}$ The conditions for detention as a measure to secure the presence of the defendant are laid down in Article 211 of the Code by stating that the detention may be ordered against a person for whom there is a reasonable doubt that he/she has committed a criminal offense if: "1) his identity is hidden or cannot be established it obviously avoids the appearance as the Accused at the main trial or if there are other circumstances indicating the danger of escape; 2) there are circumstances indicating that they will destroy, hide, modify or falsify the evidence or traces of the offense or if special circumstances indicate that they will interfere with the procedure by influencing witnesses, accomplices or concealers; 3 ) the special circumstances indicate that they will repeat the crime within a short period of time or complete the attempted criminal offense or commit the criminal offense under threat; 4) for a criminal offense he/she was charged with, there is a prescribed sentence of imprisonment for more than ten years or a prison sentence of more than five years for a criminal offense with elements of violence or a sentence of imprisonment of five years or more severely punished by the judgment of the first instance court, and the manner of execution or the severity of the consequences of the criminal act has led to disturbance of the public that can endanger the unhindered and fair conduct of criminal proceedings ..."

${ }^{59}$ G. P. Ilić et al., 739.

${ }^{60}$ Ibid.

${ }^{61}$ In addition to the obligation of the public prosecutor to inform the arrested about the rights provided for in Article 69, para. 1 of this Code, the public prosecutor shall be obliged to "allow the arrested person, in his presence, to use the telephone or other electronic messenger directly or through family members or a third person whose identity to the public prosecutor must be disclosed and, if necessary, find a defense attorney “, Art. 293, para. 1. 
If, pursuant to Article 293 of the Code, the arrested person does not provide the presence of a defense counsel within the legal period ( 24 hours) or declares that he does not want to take a defense counsel, the public prosecutor is obliged to question him without delay. In the case of a compulsory defense (in accordance with Article 74), if the arrested person does not take a defense counsel (within the legal period of 24 hours from which he was informed of this right) or declares that he/she will not be taking a defense counsel, the defense attorney will be appointed ex officio (Article 74, paragraph 2).

After hearing the suspect, the public prosecutor may release him/her or make a proposal to the pre-trial judge to order detention. In this way, the role of the preliminary procedure judge is highlighted, although it is being suppressed by the concept of a public prosecutor's investigation, since the judicial authority is primarily responsible for the preservation and decision-making regarding the rights and freedoms of the suspect. ${ }^{62}$

The police, as a body of executive power, are given a specific double role, which is reflected in the duty and obligation of protecting human rights and freedoms, on the one hand, and under the conditions prescribed by law, the restriction of these rights and freedoms, on the other. This can be achieved with full respect for the principles of legality and proportionality in the application of police powers. ${ }^{63}$

When it comes to the second aspect of the detention prescribed by the Code, the legislator foresees the possibility for each person to arrest an individual found committing a criminal offense, for which he/she will be prosecuted ex officio (Article 292, paragraph 1), imposing an obligation to hand over such a person to the public prosecutor or the police, in accordance with Art. 292, paragraph 2 of the Code.

This is understandable, since it is difficult to expect citizens to know in each specific case whether the legal presumptions for detention have been met at the time of the arrest. ${ }^{64}$

\section{DETENTION OF A SUSPECT IN POSITIVE DOMESTIC LAW (ARTICLE 294 OF THE CRIMINAL PROCEDURE LAW)}

"The detention of a suspect is a measure of procedural coercion, which, by a decision of the public prosecutor or police, if the public prosecutor entrusts the

${ }^{62}$ Of course, this does not mean that other bodies in the proceedings (public prosecutor and police) are exempted from the duty of protecting basic human rights. Each of the bodies of treatment, in addition to the code of normative duties, as a duty that has the general character, applies to all bodies, which is the very protection of human rights and freedoms, proclaimed both by national and international normative legal regulations.

${ }^{63}$ Zvonimir Ivanovic, Ivan Radojkovic, "Police Retaining Persons in the Legislation of the Republic of Serbia", Legal Topics, 2/4, Novi Pazar 2014, 8.

${ }^{64}$ Aleksandar Tresnjev, Measures to ensure the presence of the defendant and the undisturbed conduct of criminal proceedings, Belgrade 2016, 489. 
decision to it, the person deprived of liberty is being detained for a short period of time in order to collect information or to proceed with the hearing." 65 The authority to retain the suspect is an authority given to the public prosecutor so that this body would not, in particularly complex situations, be required to act within unrealistic deadlines (sometimes due to the necessity for prolonged hearing or gathering of more extensive material, the public prosecutor and the police will require additional time). If the public prosecutor was limited by the regular, short deadlines, it would often be impossible for him to adequately prepare the material that would be sent to the pre-trial judge with a motion for detention. ${ }^{66}$

Therefore, the police cannot decide by themselves to detain the person, i.e. the suspect, in pre-investigative proceedings up to 48 hours, but they may issue a decision on detaining once the prosecutor who has decided to detain the person entrusts this power to them. However, this is not an adequate legal solution, since it makes no sense that one body makes a decision, and the other (conditionally by trusting the decision-making body), practically only makes a resolution by which such a decision is formally manifested. ${ }^{67}$

The categories of persons subject to detention may be: persons arrested by the police (pursuant to Article 291, paragraph 1 of the Code), persons arrested by citizens (civil arrest, Article 292, paragraph 1 of the Code), the suspect (primarily suspect, the person summoned as a suspect, Article 289, paragraph 1 of the Code) and the person summoned as a citizen but for which, during the collection of the notifications it was determined he/she might be a suspect- subsequently suspect (Article 289, paragraph 2 of the Code).

The Code prescribes that retention, which can be determined exclusively for the purpose of questioning the suspect ${ }^{68}$ and last up to 48 hours, is determined on

${ }^{65}$ S. Knezevic, 172

${ }^{66}$ G. P. Ilić et al., 744.

${ }^{67}$ M. Škulic, T. Bugarski, 376.

${ }^{68}$ One of the most important evidence that can be collected at this stage of the proceedings is certainly the hearing of the suspect. In addition, the difference between the hearing of the suspect and the hearing of the arrested person was made (Articles 289 and 293 of the Code). While the first hearing refers to a person who responded as a suspect to a police summons, or was informed during an informative interview that the police consider him/her a suspect, the second is related to the hearing of a person arrested by the police or citizens and conducted to the public prosecutor. The hearing of the suspect may be done by the police and the public prosecutor, but the hearing of the arrested person is in the exclusive jurisdiction of the public prosecutor. The condition of the sine qua non that the testimony received at the hearing of the suspect could be used as evidence in the criminal proceedings is the presence of the defense counsel, while, when hearing the arrested person, the presence of a defense counsel is required only in the case of a compulsory defense. Another novelty is the fact that the public prosecutor decides on the detention of the suspect, and an appeal against the decision to determine detention can be appealed against by the preliminary procedure judge (Article 294, paragraphs 1 to 3 of the Code). See Goran Ilic, „Public Prosecution and Police Relations“, Criminology and Criminal Law Journal, 2-3 / 11, 319. 
the basis of a decision in the form of a resolution, which is primarily brought by the public prosecutor in accordance with the provisions of Article 294, paragraph 2 of the Code.

However, the said decision may also be made by the police, although the Code does not prescribe the original jurisdiction of the said decision-making body, but only provides such a possibility in the event of the approval of the public prosecutor. The decision on detaining the suspect, issued by the said authorities, shall be made immediately, i.e. no later than 2 hours from the moment in which the suspect was informed of his/her detention (pursuant to Article 294, paragraph 2).

Compulsory elements of the detention decision, the Code envisages in Article 294, paragraph 2 "The decision must specify the act for which the suspect is being charged for, the reasonable doubt, the day and the time of the deprivation of liberty or the response to the summons, as well as the time of the beginning of detention." The explanation of the retention order must have a reasoning and a basis for detention, having in mind the legal provisions that the police arrest is provided for in Article 291, paragraph 1 of the Code, if there are reasons for ordering detention ${ }^{69}$, in accordance with Article 211 of the Code. ${ }^{70}$

The legislator, unlike in the police arrest cases, Article 294, paragraph 3, prescribes the possibility of declaring a legal remedy, that is, the court appeal, on the decision to detain the suspect, providing for the persons who can file a remedy (the suspect and the defense counsel for the suspect) or the appeal, as well as for the deadline in which the appeal must be filed (6 hours after the delivery of the decision).

The significance of the role of the judicial authority in the pre-trial procedure is reflected in the provisions of the Code which provide that a decision on the filed appeal is made by a preliminary procedure judge within four hours, counting from the moment of receipt of the appeal. The stated regular remedy does not delay the execution of the decision (Article 294, paragraph 3 of the Code).

This act of procedural coercion in pre-trial proceedings is a specific case of compulsory defense,$^{71}$ and in addition to the aforementioned right, the suspect has rights proclaimed by Article 69, par. 1 Code.

Finally, the treatment of persons deprived of their liberty on any ground, in the sense of the constitutional principle, is prescribed as an obligation of human treatment against such persons, with the prohibition of the use of violence and extortion of the statement (Article 28 of the Constitution ${ }^{72}$ of the Republic of Serbia).

${ }^{69}$ Answer given at the session of the Criminal Department of the SCC, April 4, 2014. See Goran P. Ilić et al., 744.

${ }^{70}$ G. P. Ilić et al., 744.

${ }^{71}$ Article 294, paragraph 5 states that "The suspect must have a defense attorney as soon as the body of the proceedings ... has issued a retention order. If the suspect himself does not provide a defense counsel within four hours, the public prosecutor will provide one ex officio, in the order from the list of attorneys submitted by the competent Bar association. "

${ }^{72}$ Constitution of the Republic of Serbia, Official Gazette of RS, no. 98/2006. 


\section{ARREST AND DETENTION IN THE PRACTICE OF THE POLICE ADMINISTRATION OF ŠABAC SINCE THE YEAR 2014 UNTIL THE YEAR 2017 INCLUSIVE ${ }^{73}$}

The author conducted a research in the area of the Police Administration in Šabac, which covers the period from 01.01.2014. ending 31.12.2017. in order to determine certain parameters in relation to which the legal powers apply the measure of restricting the freedom of movement of the suspect in the pre-trial procedure are most applied.

Table and chart no. 1. depict the total number of detention and police arrest in the mentioned period, expressed as a percentage. Based on this representation, it is noticed that there is no correctness of the relationship between these two acts of procedural coercion. While the detention cases have primarily shown the increasing trend in the first three years of the research period (in order to decrease significantly during the last year), the number of arrest cases has been gradually increasing, year-by-year.

Table 1.

\begin{tabular}{|ccccccc|}
\hline PA & \multicolumn{2}{c}{ DETENTION } & \multicolumn{2}{c|}{ POLICE ARREST } & \multicolumn{2}{c|}{ TOTAL } \\
ŠABAC & NUMBER & $\%$ & NUMBER & $\%$ & NUMBER & $\%$ \\
\hline 2014 & 63 & 11.9 & 80 & 21.2 & 143 & 15.7 \\
2015 & 116 & 21.8 & 91 & 24.1 & 207 & 22.8 \\
2016 & 200 & 37.7 & 93 & 24.6 & 293 & 32.2 \\
2017 & 152 & 28.6 & 114 & 30.2 & 266 & 29.3 \\
\hline TOTAL & 531 & 100.0 & 378 & 100.0 & 909 & 100.0 \\
\hline
\end{tabular}

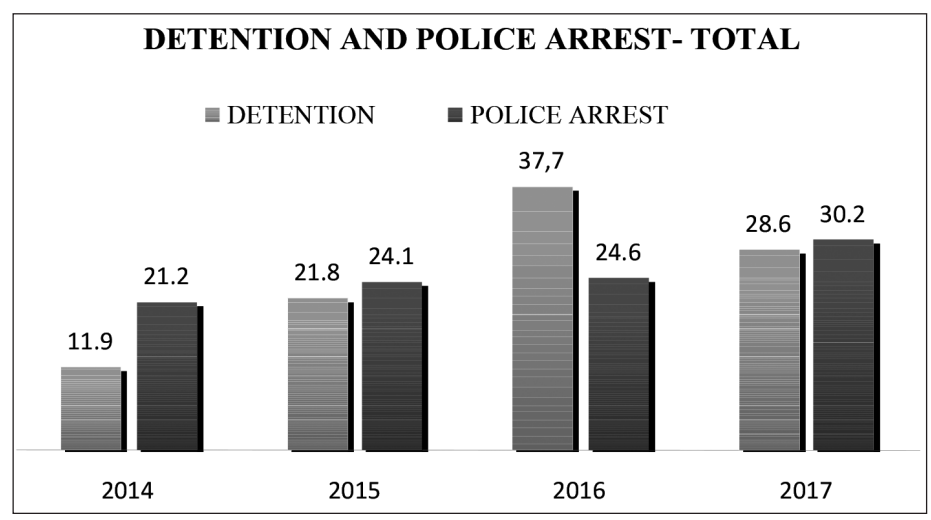

Chart 1.

${ }^{73}$ The statistics used in the work were obtained on the basis of the decisions of the Higher Public Prosecutor's Office in Šabac A No. 131/18 of 30 March 2018. the Police Administration in Šabac, 05/19/7, No. 118/18 of 04 April 2018, and a direct insight into the decision made by the Basic Public Prosecutor's Office in Šabac on April 5, 2018. 
The following table-graphic representation (tables 2 and 3, Charts 2 and 3) refers to the individually shown measures limiting the freedom of movement of the suspect in the pre-investigation process, in order to better understand the above-mentioned irregularities.

Table 2 .

\begin{tabular}{|ccc|}
\hline PA ŠABAC & DETENTION \\
& NUMBER & $\%$ \\
\hline 2014 & 63 & 11.9 \\
2015 & 116 & 21.8 \\
2016 & 200 & 37.7 \\
2017 & 152 & 28.6 \\
\hline TOTAL & 531 & 100.0 \\
\hline
\end{tabular}

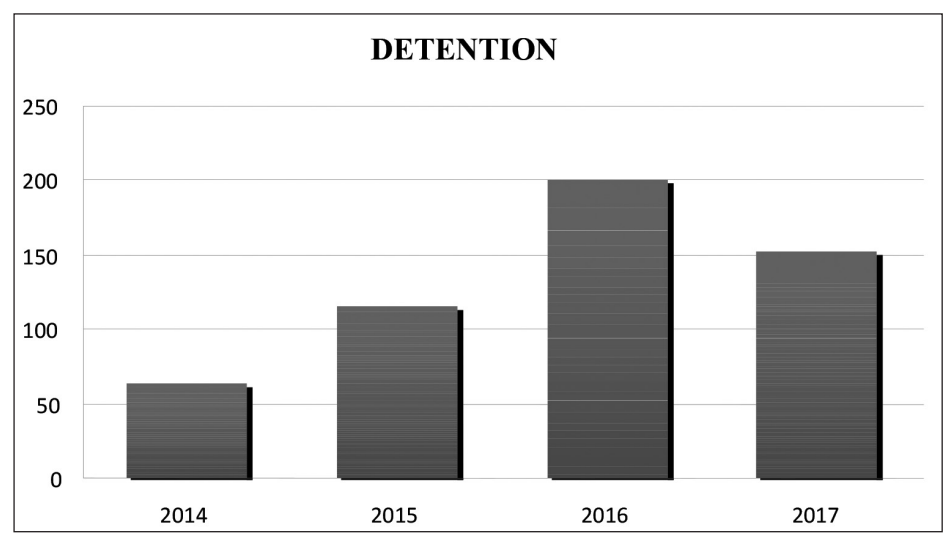

Chart 2.

Table 3.

\begin{tabular}{|ccc|}
\hline \multirow{2}{*}{ PA ŠABAC } & \multicolumn{2}{c|}{ POLICE ARREST } \\
& NUMBER & $\%$ \\
\hline 2014 & 80 & 21.2 \\
2015 & 91 & 24.1 \\
2016 & 93 & 24.6 \\
2017 & 114 & 30.2 \\
\hline TOTAL & 378 & 100.0 \\
\hline
\end{tabular}




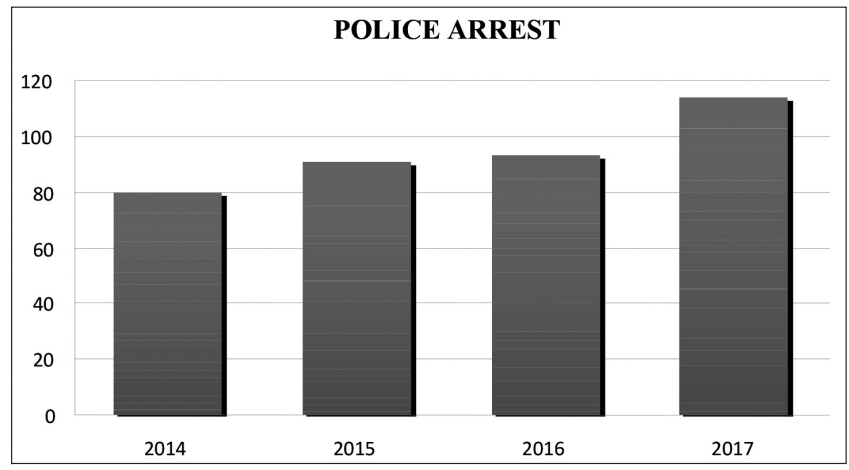

Chart 3.

When it comes to the gender of the persons according to which the measures of restraint of freedom of movement in the pre-investigative procedure are applied, from the following representations (table and chart 4) it is noted that, each year, the male population is the dominant category, whereas the female population is far away less affected by the aforementioned measures of procedural coercion, although there is still a trend of increasing the number of women against which these measures are applied, year-by-year.

Table 4 .

\begin{tabular}{|ccccccccccccc|}
\hline \multirow{2}{*}{ PA } & \multicolumn{3}{c}{ DETENTION } & \multicolumn{3}{c}{ POLICE ARREST } & \multicolumn{3}{c|}{ TOTAL } \\
ŠABAC & \multicolumn{2}{c}{ MALE } & \multicolumn{2}{c}{ FEMALE } & \multicolumn{2}{c|}{ MALE } & \multicolumn{2}{c|}{ FEMALE } & \multicolumn{2}{c|}{ MALE } & \multicolumn{2}{c|}{ FEMALE } \\
& No. & $\%$ & No. & $\%$ & No. & $\%$ & No. & $\%$ & No. & $\%$ & No. & $\%$ \\
\hline 2014 & 60 & 11.9 & 3 & 11.1 & 76 & 21.0 & 4 & 25.0 & 136 & 15.7 & 7 & 16.3 \\
2015 & 108 & 21.4 & 8 & 29.6 & 89 & 24.6 & 2 & 12.5 & 197 & 22.7 & 10 & 23.3 \\
2016 & 192 & 38.1 & 8 & 29.6 & 86 & 23.8 & 7 & 43.8 & 278 & 32.1 & 15 & 34.9 \\
2017 & 144 & 28.6 & 8 & 29.6 & 111 & 30.7 & 3 & 18.8 & 255 & 29.4 & 11 & 25.6 \\
\hline TOTAL & 504 & 100.0 & 27 & 100.0 & 362 & 100.0 & 16 & 100.0 & 866 & 100.0 & 43 & 100.0 \\
\hline
\end{tabular}

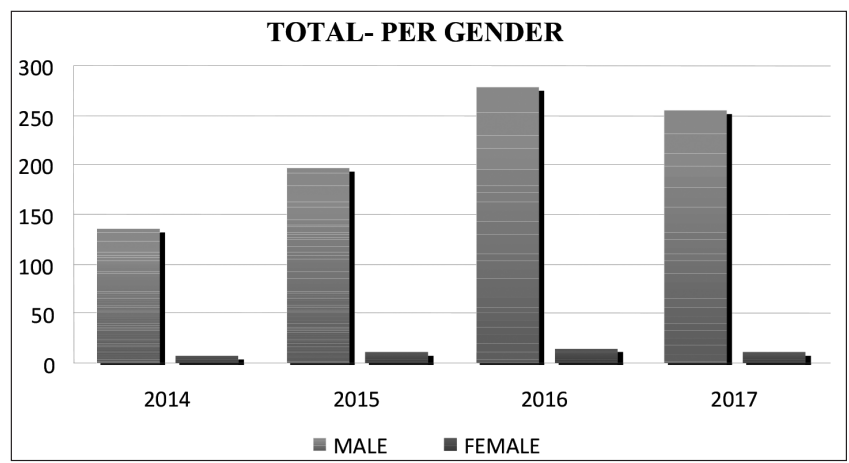

Chart 4. 
In relation to the parameter of the age of a person who was deprived of freedom of movement by detention or arrest, it can be seen from the table that minors (persons under 18) are the least affected age category, followed by persons over 60, persons aged 41-60 years, and that these measures were mostly taken against persons aged between 21 and 40. From the above, it can be concluded that, in the majority of cases, mostly middle-aged persons are being suspected of committing criminal offenses.

Table 5.

\begin{tabular}{|c|c|c|c|c|c|c|c|c|c|c|}
\hline \multirow{3}{*}{$\begin{array}{c}\text { PA } \\
\text { ŠABAC }\end{array}$} & \multicolumn{2}{|c|}{2014} & \multicolumn{2}{|c|}{2015} & \multicolumn{2}{|c|}{2016} & \multicolumn{2}{|c|}{2017} & \multicolumn{2}{|c|}{ TOTAL } \\
\hline & 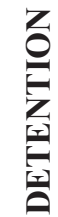 & 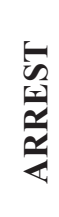 & 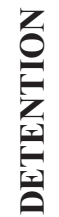 & 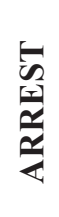 & 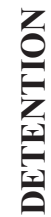 & 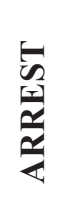 & 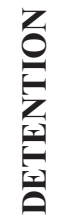 & $\begin{array}{l}\sqrt{n} \\
\frac{n}{\alpha} \\
\underline{a}\end{array}$ & 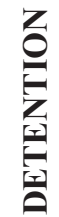 & 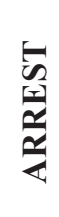 \\
\hline & No. & No. & No. & No. & No & No. & No. & No. & No. & No. \\
\hline 14 и 15 & 0 & 0 & 0 & 0 & 0 & 0 & 1 & 2 & 1 & 2 \\
\hline 16 и 17 & 0 & 2 & 4 & 1 & 1 & 1 & 3 & 3 & 8 & 7 \\
\hline $18-20$ & 6 & 7 & 13 & 8 & 18 & 8 & 5 & 7 & 42 & 30 \\
\hline $21-30$ & 27 & 25 & 37 & 26 & 47 & 26 & 40 & 26 & 152 & 102 \\
\hline $31-40$ & 15 & 24 & 33 & 22 & 63 & 23 & 47 & 38 & 158 & 107 \\
\hline $41-50$ & 10 & 9 & 14 & 13 & 36 & 20 & 24 & 20 & 84 & 62 \\
\hline $51-60$ & 3 & 9 & 11 & 15 & 22 & 12 & 21 & 12 & 57 & 48 \\
\hline $60+$ & 3 & 4 & 4 & 6 & 11 & 3 & 11 & 7 & 29 & 20 \\
\hline TOTAL & 65 & 80 & 116 & 91 & 201 & 93 & 152 & 115 & 531 & 378 \\
\hline
\end{tabular}

Certainly, the indispensable criterion, which is shown in table no. 6 , refers to the type of crime. Taking into account the daily presence of certain types of crime, it is quite possible to reach the established results. Namely, the leading place is taken by the general criminality, i.e. crimes against life and body, property, sexual freedom, human health, as well as marriage and family; then criminal offenses against the economy and the environment, while for crimes against the constitutional order and security of the Republic of Serbia and the security of computer data, no measures were imposed to restrict the freedom of movement towards suspects in pre-trial proceedings. 
Table 6 .

\begin{tabular}{|c|c|c|c|c|c|c|c|c|c|c|}
\hline \multirow{3}{*}{$\begin{array}{c}\text { PA } \\
\text { ŠABAC }\end{array}$} & \multicolumn{2}{|c|}{2014} & \multicolumn{2}{|c|}{2015} & \multicolumn{2}{|c|}{2016} & \multicolumn{2}{|c|}{2017} & \multicolumn{2}{|c|}{ TOTAL } \\
\hline & 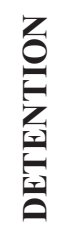 & $\begin{array}{l}\frac{5}{2} \\
\frac{\pi}{2} \\
\frac{2}{2} \\
\frac{\pi}{4}\end{array}$ & 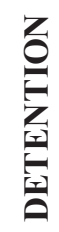 & 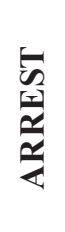 & 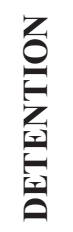 & 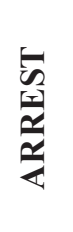 & 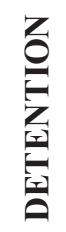 & 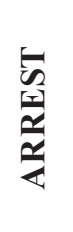 & 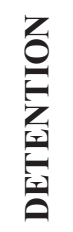 & 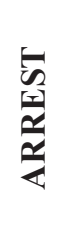 \\
\hline & No. & No. & No. & No. & No. & No. & No. & No. & No. & No. \\
\hline $\begin{array}{l}\text { CRIME AGAINST } \\
\text { ECONOMY }\end{array}$ & 0 & 5 & 12 & 2 & 5 & 5 & 8 & 1 & 25 & 13 \\
\hline $\begin{array}{l}\text { CRIME AGAINST } \\
\text { THE ENVIRONMENT }\end{array}$ & 0 & 0 & 0 & 0 & 0 & 0 & 4 & 4 & 4 & 4 \\
\hline $\begin{array}{c}\text { CRIME AGAINST THE } \\
\text { CONSTITUTIIONAL } \\
\text { ORDER AND SECURITY } \\
\text { OF THE RS }\end{array}$ & 0 & 0 & 0 & 0 & 0 & 0 & 0 & 0 & 0 & 0 \\
\hline $\begin{array}{c}\text { CRIME AGAINS LIFE } \\
\text { AND BODY, PROPERTY, } \\
\text { SEXUAL FREEDOM, } \\
\text { HEALT, MARRIAGE } \\
\text { AND FAMILY }\end{array}$ & 63 & 75 & 104 & 89 & 195 & 88 & 140 & 109 & 502 & 361 \\
\hline $\begin{array}{l}\text { CRIME AGAINS THE } \\
\text { SECURITY OD THE } \\
\text { COMPUTER DATA }\end{array}$ & 0 & 0 & 0 & 0 & 0 & 0 & 0 & 0 & 0 & 0 \\
\hline TOTAL & 63 & 80 & 116 & 91 & 200 & 93 & 152 & 114 & 531 & 378 \\
\hline
\end{tabular}

Finally, table no. 7. represents the most common crimes, for whose execution, in most cases, the suspected person has been deprived of the freedom of movement by the organs of pre-trial proceedings. The significance of this individual representation stems from the efforts to determine which crimes are most dominant in the practice of the Police Administration in Šabac. 
Table 7.

\begin{tabular}{|c|c|c|c|c|c|c|c|c|c|c|}
\hline \multirow{3}{*}{ PA ŠABAC } & \multicolumn{2}{|c|}{2014} & \multicolumn{2}{|c|}{2015} & \multicolumn{2}{|c|}{2016} & \multicolumn{2}{|c|}{2017} & \multicolumn{2}{|c|}{ TOTAL } \\
\hline & 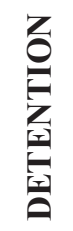 & 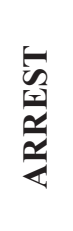 & 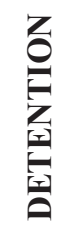 & 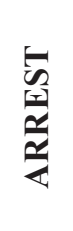 & 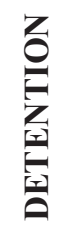 & $\begin{array}{l}\frac{1}{n} \\
\frac{5}{\alpha} \\
\frac{1}{2} \\
\frac{1}{4}\end{array}$ & 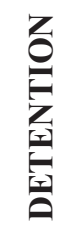 & $\begin{array}{l}\frac{1}{6} \\
\frac{n}{c} \\
\frac{x}{2} \\
\frac{x}{4}\end{array}$ & 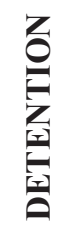 & 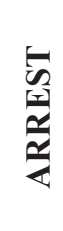 \\
\hline & No. & No. & No. & No. & No. & No. & No. & No. & No. & No. \\
\hline MURDER - art. 113of CC & 6 & 4 & 8 & 3 & 2 & 2 & 3 & 0 & 19 & 9 \\
\hline $\begin{array}{c}\text { FIRST-DEGREE } \\
\text { MURDER - art. 114of CC }\end{array}$ & 2 & 1 & 1 & 0 & 10 & 1 & 0 & 1 & 13 & 3 \\
\hline $\begin{array}{l}\text { SERIOUS BODILY IN- } \\
\text { JURY - art. 121of CC }\end{array}$ & 1 & 2 & 1 & 1 & 1 & 6 & 4 & 0 & 7 & 9 \\
\hline RAPE - art. 178of CC & 0 & 0 & 0 & 2 & 3 & 0 & 1 & 1 & 4 & 3 \\
\hline THEFT - art. 203of CC & 3 & 3 & 0 & 2 & 8 & 3 & 5 & 3 & 16 & 11 \\
\hline $\begin{array}{l}\text { HEAVY THEFT - art. } \\
\text { 204of CC }\end{array}$ & 7 & 9 & 11 & 2 & 33 & 2 & 16 & 4 & 67 & 17 \\
\hline ROBBERY - art. 206of CC & 9 & 5 & 27 & 9 & 14 & 3 & 12 & 5 & 62 & 22 \\
\hline $\begin{array}{l}\text { DOMESTIC VIOLENCE } \\
\text { - art. 194of CC }\end{array}$ & 5 & 3 & 23 & 28 & 84 & 42 & 71 & 42 & 183 & 115 \\
\hline $\begin{array}{c}\text { ILLEGAL PRODUCTION } \\
\text { AND TRAFFICING OF } \\
\text { DRUGS - art. 246of CC } \\
\text { UNAUTHORISED }\end{array}$ & 18 & 7 & 18 & 4 & 21 & 3 & 13 & 4 & 70 & 18 \\
\hline $\begin{array}{c}\text { POSSESION OF DRUGS } \\
\text { - art. 246Aof CC }\end{array}$ & 0 & 5 & 1 & 2 & 7 & 5 & 1 & 9 & 9 & 21 \\
\hline $\begin{array}{c}\text { SERIOUS CRIME } \\
\text { AGAINST THE } \\
\text { SECURITY OF PUBLIC } \\
\text { TRAFIC - art. 297of CC }\end{array}$ & 0 & 8 & 0 & 10 & 0 & 6 & 0 & 6 & 0 & 30 \\
\hline TOTAL & 51 & 47 & 90 & 63 & 183 & 73 & 126 & 75 & 450 & 258 \\
\hline
\end{tabular}

In the end, it is important to note that during the above research period, the Higher Public Prosecutor's Office in Šabac did not issue any decision to keep a the suspect in custody during the pre-trial procedure, while the Basic Public Prosecutor's Office in Šabac issued only one such decision, and all other decisions on detaining the suspect were made by the police. Bearing in mind the abovementioned, the conclusion is drawn that the implementation of the legal provisions in practice, relating to the original jurisdiction for the adoption of the said decision by the Public Prosecutor's Office, is an exception. 


\section{CONCLUSION}

Starting from the first legal solutions in the criminal process practice of Serbia, significant powers of state authorities related to the restriction of the freedom of movement of the suspect in the phases preceding the formal criminal procedure are obvious.

Historically, the legal authority to undertake the measures of deprivation of liberty of the suspect in pre-trial proceedings was placed in the hands of the internal affairs organs, the public prosecutor and the judicial authorities, with complete absence or recognition of some of the suspects' rights. The initial solutions featured much less guarantees of protection of the procedural position of the suspect compared to the one that exists today in positive law.

As the proclaiming of certain rights and freedoms, among other things, has the role of limitation of the state power, the evolution of the level of protected rights itself depends on the relationship between the individual and the state. Thus, the initial criminal procedural solutions were far from the ideal of justice, bearing in mind the non-proscribing of the right to a defence for the suspect. However, raising the awareness of the state and society as well as the liberalization of the said relationship, the rights of persons who are bearers of deviant, anti-social behavior have been gradually legalized (the right to a defense during the entire procedure is prescribed, along with the mandatory defense, the right to material compensation due to unfounded deprivation of liberty etc.), which consequently results in a significant improvement in the procedural position of the suspect and the efforts to achieve procedural equality of the parties in the criminal procedure.

The criticism of the expert public in relation to earlier legal solutions concerned primarily the prescribing of the possibility of non-judicial bodies to order detention, which is almost unthinkable today, especially given the role of the court as an independent state body that decides on the restrictions of rights and the freedom of the defendant in the criminal proceedings.

However, this postulate of humanity and democracy is being opposed by a demand for an effective fight against crime, for the protection of fundamental social values. In that sense, the constitution of modern states as well as international legal regulations prescribe the possibility of restricting the freedom of movement of the suspect and by non-judicial authorities as well - the police and the public prosecutor.

This, of course, does not mean that there is no prohibition against arbitrary actions of public authorities, since they are authorized by the Constitution and by the law to take measures of deprivation of liberty under strictly predicted conditions. Recognizing the importance of adequately confronting increasingly diverse forms of crime and its bearers, normative acts not only give the authority to limit the freedom of movement to state bodies, but to citizens as well. 


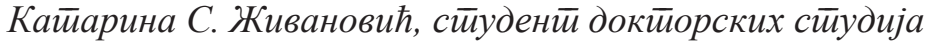

Универзииетеи у Новом Саду

Правни факулиетеи у Новом Саду

kaca_zivanovic@yahoo.com

\section{Ограничење слободе кретања осумњиченог у предистражном поступку}

Сажеейак: Темељи савременог̄, демокрайског̄ друщйва засновани на

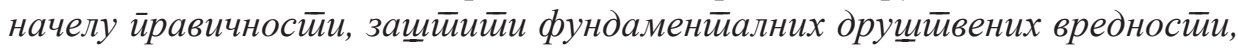

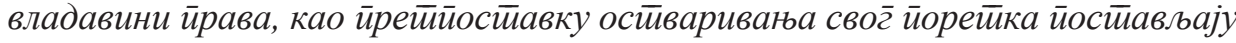
слободно и несметиано уживање йрокламованих људских йрава и слобода.

Међутиим, у одређеним случајевима, а у изиьу остиваривана кривично-йрав-

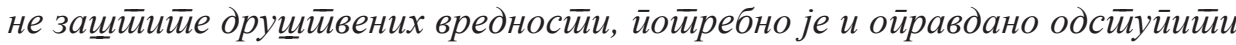
од, на националном и међународном нивоу загаранитованих йрава и слобода. Устиави савремених држава, уг̆лавном йакво огрраничење своде само на случајеве „изузетиностии“, у стирог̄o нормираним условима. Тиме долази до одстичйања од ирокламоване неирикосновеносиии ирава на личну слободу, гेде је тиакво ограничавање дойщииено у одређеном обиму и сврси, без задирања

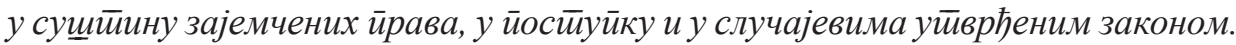

Огрраничење слободе кретиања осумњиченог, ирройисује се ирвенсиивено у изиљу вођень кривичног йостиуйка одлуком коју у иичсаној форми доноси надлежан судски орг̄ан. Међуйим, ради йостиизаға ефикасностии кривичног̄

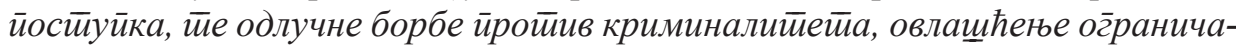
вања слободе кретиања у виду хайщења и задржавања дайо је и друг̄им државним орг̃анима.

Кључне речи: ограничење слободе крейања, осумњичени, йоличија, хайщење, задржавање.

Датум пријема рада: 12.09.2018. 